\title{
Celebrating the 70th Birthday of Professor Shigeru Terabe
}

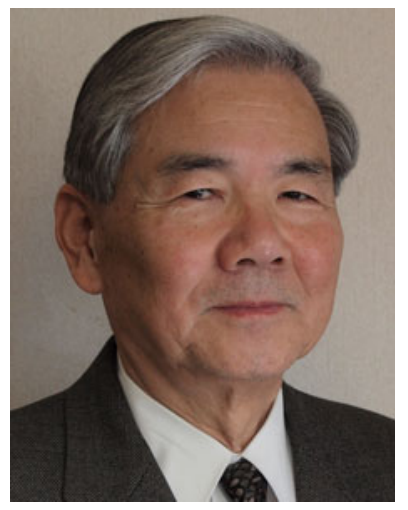

Professor Shigeru Terabe (Professor Emeritus of the University of Hyogo) will celebrate his 70th birthday on the 21 October 2010. It is a great pleasure to congratulate Professor Terabe on this occasion. The title of the traditional 70 years old celebration, "Koki" in Japanese, is originally found in a poem of Toho (Japanese pronunciation of $\mathrm{Du} \mathrm{Fu}$, 712-770), a great Chinese poet. The poem declares that "Life for 70 years is rare since old times." Healthy and happy life of 70 years still deserves congratulations even today. "Koki" is customarily celebrated one year earlier, to include the year of birth (1940 for Professor Terabe) and each new year after that is counted.

The scientific contributions of Professor Terabe were given in Chromatographia in 2000 on the occasion of his 60th birthday [1] and in a special issue of the Journal of Chromatography A in 2006 [2]. When Professor Terabe retired from the University of Hyogo at 65, he did not completely retire from his academic life. He served as a Research Supervisor of the programme "Precursory Research for Embryonic Science and Technology" funded by the government for the period 2004-2010, assisting 40 top young analytical scientists by funding ca. 5 million USD per year for the project, "Structure Function and Measurement Analysis". The project ended in 2010 with numerous interesting and important findings. Professor Terabe served as an editor of Journal of Chromatography $A$ for the period 1994-2009. He has been appointed a Special Professor at Kyoto University, his alma mater, since 2006. He is now serving as Chairman of the IUPAC International Congress on Analytical Sciences (ICAS) 2011 to be held in Kyoto in May next year.

The first papers on "Micellar Electrokinetic Chromatography" published in 1984 [3] and in 1985 [4] have been cited 1,442 and 993 times up to 1 September, of this year. His over 250 original research publications have been cited more than 15,000 times altogether, ranked in the top 200 among all chemists. The papers still continue contributing to analytical chemistry. After receiving the ACS Award in Chromatography in 2004, Professor Terabe received the CaSSS Award (California Separation Science Society) in 2007, and the Chemical Society of Japan Award (2008) in recognition of his contributions to analytical chemistry.

Since 2005, Professor Terabe has been enjoying his private retirement life in Moriyama, Japan, spending time for listening music, reading books, and organizing many photographs at home and in his condominium on the shore of Lake
Biwa about $5 \mathrm{~km}$ from his home. He serves as president of the residents' association of the local community. For his Koki celebration, his wife (Mrs. Yoshie Terabe) and the families of his three sons, including six grandchildren, three girls $(9$, 5 and 1 years old) and three boys (8, 4 years, and 9 months old) gathered together to congratulate him last July. It is his greatest pleasure to be surrounded by the small grandchildren. Professor Terabe also enjoys seeing the success of his former students and postdoctoral fellows, many of whom occupy key positions in academia and industry. As those who learned from what Professor Terabe has done, we congratulate him on his 70th birthday, and wish him and his family good health.
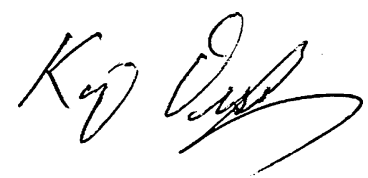

Koji Otsuka, Kyoto University

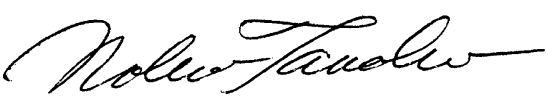

Nobuo Tanaka, Kyoto Institute of Technology and GL Sciences, Inc.

\section{References}

1. Tanaka N, Otsuka K (2000) Chromatographia 52:394

2. Tanaka N (2006) J Chromatogr A 1106:6

3. Terabe S, Otsuka K, Ichikawa K, Tsuchiya A, Ando T (1984) Anal Chem 56:111-113

4. Terabe S, Otsuka K, Ando T (1985) Anal Chem 57:834-841 